\title{
Modeling Human Exposure Levels to Airborne Volatile Organic Compounds by the Hebei Spirit Oil Spill
}

\author{
Jong Ho Kim¹, Byoung Kyu Kwak², Mina Ha ${ }^{3}$, Hae-Kwan Cheong ${ }^{4}$, Jongheop Yi \\ 'Supply Chain Logistics Consulting Team, Samsung SDS, Seoul, ${ }^{2}$ School of Chemical and Biological Engineering, Institute of Chemical Process, College of \\ Engineering, Seoul National University, Seoul, ${ }^{3}$ Department of Preventive Medicine, Dankook University College of Medicine, Cheonan; ${ }^{4}$ Department of Social \\ and Preventive Medicine, Sungkyunkwan University School of Medicine, Suwon, Korea
}

Objectives: The goal was to model and quantify the atmospheric concentrations of volatile organic compounds (VOCs) as the result of the Hebei Spirit oil spill, and to predict whether the exposure levels were abnormally high or not.

Methods: We developed a model for calculating the airborne concentration of VOCs that are produced in an oil spill accident. The model was applied to a practical situation, namely the Hebei Spirit oil spill. The accuracy of the model was verified by comparing the results with previous observation data. The concentrations were compared with the currently used air quality standards.

Results: Evaporation was found to be 10- to 1,000-fold higher than the emissions produced from a surrounding industrial complex. The modeled concentrations for benzene failed to meet current labor environmental standards, and the concentration of benzene, toluene, orthometa- para-xylene were higher than the values specified by air quality standards and guideline values on the ocean. The concentrations of total VOCs were much higher than indoor environmental criteria for the entire Taean area for a few days.

Conclusions: The extent of airborne exposure was clearly not the same as that for normal conditions.

Key words: Air dispersion, California puff, Evaporation, Simulation, Volatilization

\section{INTRODUCTION}

Accidental oil spills are occurred frequently and can have severe adverse effects on the marine environment and human health. During the period 1970 to 2007, about 46 oil spills occurred per year and accounted for one hundred fifteen thousand tons of spilled oil. In addition, many oil spills typically occur near coastal areas [1].

The oil tanker Hebei Spirit collided with a crane barge on December 7, 2007, $8 \mathrm{~km}$ off the west coast of the Taean region in South Korea. The Hebei Spirit subsequently released an estimated 12,547 kL of crude oil. About 58,000 citizens live in Taean, and more than 870,000 persons were involved in clean-up activities, including volunteers, army personnel, police, public servant, inhabitants, and specialized companies. It is likely that the clean-up workers and inhabitants, including elderly and weak people were exposed to high levels of evaporated volatile organic compounds (VOCs), and that this exposure likely had an impact on the health of people who were present at that time. In fact, adverse health effects as the result of exposure to VOCs have been reported in several studies of other oil spill accidents [2-5]. However, at the case of the Hebei Spirit oil spill accident, subsequent initial airborne exposure measurements were not carried out to confirm this, as has often been the case with other oil spill accidents. Without observation data regarding airborne VOCs concentrations, a modeling study is the only solution for estimating inhalation exposure which plays an important role in assessing possible adverse health effects.

Several research groups had developed computational models for calculating the fate of spilled oil [6-18]. These models generally focused on the movement of an oil slick on the sea surface from the standpoint of weather-related processes such as evaporation, emulsification and dissolution. These models have proven to be useful for predicting the fate of an oil slick and changes in the physicochemical properties of the slick, and have affected

Correspondence: Jongheop Yi, PhD

559 Gwanak-ro, Gwanak-gu, Seoul 151-742, Korea

Tel: +82-2-880-7438, Fax: +82-2-885-6670

E-mail: jyi@snu.ac.kr

Received: Feb 10, 2011, Accepted: Jan 6, 2012, Published Online: Mar 22, 2012 This article is available from: http://e-eht.org/ 
contingency plans and immediate protection strategy for protecting the coast line from contamination. However, our current understanding of the dispersion of evaporated oil components into the air remains incomplete, although air dispersion is an important factor in the inhalation exposure of toxic volatile oil components for humans.

Herein, a modeling technique is proposed that permits the atmospheric concentrations of VOCs to be assessed after an oil spill. The modeling technique was developed by integrating the weathering model and the California Puff (CALPUFF) air dispersion model, and was applied to the Hebei Spirit oil spill. Our main aim was to assess the levels of VOCs that clean-up workers, as well as inhabitants, were exposed to and to predict the adverse effect of these levels on human health. This modeling study resulted in important information that promises to be useful in predicting adverse effects of such components on human health and in future guidelines for subsequent epidemiological studies.

\section{MATEIALS AND METHODS}

The current section describes the available algorithms and data that are currently used to assess the evaporation rate of VOCs considering other weather-related processes, and illustrates the methods used to predict the concentration of evaporated compounds in air by the air dispersion model. The algorithms for evaporation with other weathering processes typically draw upon previously developed algorithms. The dispersion and concentration of VOCs in an atmospheric environment is predicted by employing a CALPUFF model, and various types of observation data (wind, current, aerial photographs, satellite images, etc) was introduced into the models. Each algorithm and method is described individually. The integration of the different algorithms and methods needs to reflect the fact that they interact with each other.

\section{Accident Scenario}

In the Hebei Spirit oil spill, three types of crude oil, United Arab Emirates Upper Zakum, Kuwait export crude and Iranian heavy crude, were released over a period of about 6 hours. To calculate changes in the physicochemical properties of the spilled oil, it is necessary to define their initial properties. The averaged physicochemical properties for the three kinds of crude oil were used as the initial properties. The values for the average American Petroleum Institute gravity, Reid vapor pressure, density and the dynamic viscosity of initial crude oil properties were 31.4 , $46 \mathrm{kPa}, 865 \mathrm{~kg} / \mathrm{m}^{3}$ and $56 \mathrm{cP}$, respectively.

\section{Oil Slick Spreading}

The rate of spreading of the oil slick is based on the gravity-viscous formulation proposed previously by Drivas [6] and Hoult [7] and later modified by Mackay et al. [10]. The spreading rate is calculated as:

$$
\frac{d A}{d t}=K_{1} \frac{V^{\frac{4}{3}}}{A}
$$

where $A=$ the area of the slick $\left(\mathrm{m}^{2}\right), V=$ volume of the oil slick $\left(\mathrm{m}^{3}\right), K_{1}=$ a constant with a default value of $150 \mathrm{~s}^{-1}$ and $t=$ time (s).

To solve equation 1 by a numerical method, an analytical solution was adopted for use as the initial conditions. Lehr et al. [11] developed an analytical formula that is suitable for estimating the initial size of a spill given the observed area of the spill.

$$
A=998.928\left[\frac{\rho-\rho_{0}}{\rho_{0}}\right]^{\frac{2}{3}} V^{\frac{2}{3}} t^{\frac{1}{2}}+3.102\left[\frac{\rho-\rho_{0}}{\rho_{0}}\right]^{\frac{1}{3}} V^{\frac{1}{3}} W^{\frac{4}{3}} t
$$

where $\rho_{0}=$ density of the oil $\left(\mathrm{g} / \mathrm{m}^{3}\right), \quad \rho=$ density of the water $\left(\mathrm{g} / \mathrm{m}^{3}\right)$ and $W=$ the wind speed $(\mathrm{m} / \mathrm{s})$. The spreading process generally ceases at a terminal thickness of $0.1 \mathrm{~mm}$ for heavy crude oils [17]. The algorithm assumes a uniform thickness $\mathrm{h}(\mathrm{m})$, which can be calculated as:

$$
h=\frac{V}{A}
$$

\section{Evaporation}

Evaporation is generally considered to be the primary process resulting in the loss of light ingredients during the first few hours of an oil spill [9]. To assess the evaporation rate, we applied the pseudo-component approach that has been described in previous studies [8]. The pseudocomponent approach characterizes the mass of the individual hydrocarbon components evaporated, grouped by vapor pressure fraction.

$$
\frac{d m_{i}}{d t}=\frac{K_{2} P_{i} A f_{i} M_{i}}{R T}
$$

where $m_{i}=$ mass of the $\mathrm{i}^{\text {th }}$ component $(\mathrm{g}), P_{i}=$ vapor pressure (atm), $f_{i}=$ fraction of spill which is constituent $\mathrm{i}, R$ $=$ the gas constant $\left(8.206 \mathrm{E}^{-5} \mathrm{~atm} \mathrm{m^{3 }} / \mathrm{mol} \mathrm{K}\right), T=$ tempreature $(\mathrm{K})$ and $K_{2}=$ mass transfer coefficient $(\mathrm{m} / \mathrm{s})$ given by Mackay et al. [10], expressed as:

$$
K_{2}=0.029 W^{-0.78} D^{-0.11} S_{c}^{-0.67} \approx 2.5 X 10^{-3} W^{0.78}
$$

where $W=$ the wind speed $(\mathrm{m} / \mathrm{s}), D=\operatorname{spill}$ diameter $(\mathrm{m})$ and $S c=$ the Schmidt number.

To apply the pseudo-component approach for identifying 
Table 1. Weight fraction and physicochemical properties of crude oil ingredients for the oil spill weathering model [8]

\begin{tabular}{|c|c|c|c|c|c|c|}
\hline No. & Material & $\begin{array}{l}\text { Weight } \\
\text { fraction }\end{array}$ & $\begin{array}{l}\text { Molecular } \\
\text { weight } \\
(\mathrm{g} / \mathrm{moL})\end{array}$ & $\begin{array}{l}\text { Average } \\
\text { density } \\
\left(\mathrm{kg} / \mathrm{m}^{3}\right)\end{array}$ & $\begin{array}{l}\text { Average } \\
\text { solubility } \\
\left(\mathrm{g} / \mathrm{m}^{3}\right)\end{array}$ & $\begin{array}{l}\text { Vapor pressure }(\mathrm{Pn}, \mathrm{mm} \mathrm{Hg}) \text { at a } \\
\quad \text { given temperature }(\mathrm{T}, \mathrm{K})\end{array}$ \\
\hline 1 & Paraffin (C6 - C12) & 0.15 & $86-170$ & 710 & 4.755 & $\log P_{1}=6.94-1417.61 /(-70.98+T)$ \\
\hline 2 & Paraffin (C13 - C25) & 0.15 & $184-352$ & 770 & 0.007 & $\log P_{2}=7.01-1825.04 /(-123.39+T)$ \\
\hline 3 & Cycloparaffin (C6 - C12) & 0.2 & $84-164$ & 810 & 28 & $\log P_{3}=6.91-1441.79 /(-68.45+T)$ \\
\hline 4 & Cycloparaffin (C13 - C23) & 0.2 & $156-318$ & 900 & 0.5 & $\log \mathrm{P}_{4}=6.99-1893.78 /(-121.33+\mathrm{T})$ \\
\hline 5 & Aromatic mono and dicyclic (C6 - C11) & 0.042 & $78-143$ & 940 & 890 & $\log P_{5}=6.91-1407.34 /(-64.67+\mathrm{T})$ \\
\hline 6 & Aromatic poly - cyclic $(\mathrm{C} 12-\mathrm{C} 18)$ & 0.03 & $128-234$ & 1000 & 6.25 & $\log \mathrm{P}_{6}=6.97-1801.00 /(-110.38+\mathrm{T})$ \\
\hline 7 & Naphtheno - aromatic (C9 - C25) & 0.07 & $116-300$ & 980 & 0.5 & $\log \mathrm{P}_{7}=6.97-1789.85 /(-108.59+\mathrm{T})$ \\
\hline 8 & Residual including heterocycles & 0.15 & $300-900$ & 1010 & 0 & $\mathrm{P}_{8}=0$ \\
\hline 9 & Benzene & 0.001 & 78.11 & 878.6 & 800 & $\log \left(\mathrm{P}_{9} / 7.6\right)=-8.43 \log (\mathrm{T})+(-6281 / \mathrm{T})+71.11+6.2{ }^{6} \mathrm{~T}^{2}$ \\
\hline 10 & Toluene & 0.003 & 92.14 & 867 & 526 & $\log \left(\mathrm{P}_{10} / 7.6\right)=-8.80 \log (\mathrm{T})+(-6918 / \mathrm{T})+74.14+5.75-{ }^{-} \mathrm{T}^{2}$ \\
\hline 11 & Ethylbenzene & 0.001 & 106.17 & 867 & 206 & $\left.\log \left(P_{11} / 7.6\right)=-9.55 \log (T)+-7638 / T\right)+79.79+5.65-{ }^{-} T^{2}$ \\
\hline 12 & ortho-, meta-, para-Xylene & 0.003 & 106.17 & 870 & 0 & $\mathrm{P}_{12}=5.16$ \\
\hline
\end{tabular}

\section{$\mathrm{C}$, number of carbon atoms.}

the evaporation profile of chemicals, the physicochemical properties of the crude oil are required. The range of physical and chemical properties for each fraction is summarized in Table 1.

\section{Emulsification}

Under the influence of sea waves, water droplets are entrained by the oil slick, resulting in the formation of a water-in-oil emulsion. Mackay et al. [10] proposed the following expression for calculating the rate of incorporation of water into an oil slick:

$$
\frac{d Y_{W}}{d t}=2.0 X 10^{-6}(W+1)^{2}\left(1-\frac{Y_{W}}{C_{1}}\right)
$$

where $Y_{w}=$ the fraction of water in the oil, $C_{l}=$ final water content fraction ( 0.7 for crude oils and heavy fuel oil).

\section{Vertical Dispersion and Mechanical Removal}

Under the action of waves, especially breaking waves, the oil slick tends to break up, resulting in the formation of small oil droplets (diameter $<0.1 \mathrm{~mm}$ ). The small droplets are incorporated in the water column during the natural horizontal dispersion process [18]. These processes are defined as natural vertical dispersion.

In many oil spill accidents, dispersants and mechanical removal techniques are utilized to prevent long range horizontal dispersion and coastal pollution. The dispersant increases the velocity at which oil droplets are incorporated into the water column, and mechanical removal can prevent an oil slick from reaching a coastal area. In this study, the vertical dispersion (natural dispersion and accelerated dispersion by dispersants) and mechanical removal are regarded as total removal process, because these processes decrease the evaporation rate of volatile materials. The removal process can be expressed as follows:

$$
\frac{d V}{d t}=-D_{n} V-D_{d} V-V_{m}
$$

where $D_{n}$ and $D_{d}=$ the entrainment coefficient cause of the natural dispersion and dispersant spraying, respectively $\left(\mathrm{s}^{-1}\right)$, The $V_{m}\left(\mathrm{~m}^{3} / \mathrm{s}\right)=$ the volume of oil components removed by mechanical removal. Reed [17] computed $D n$ by employing the entrainment formulation of Mackay et al. [10], which is expressed as:

$$
D_{n}=D_{a} D_{b}=[0.11(W+1) 2]\left[1+50 \mu^{\frac{1}{2}} h S_{t}\right]
$$

where $D a=$ the fraction of sea surface dispersed per hour, $D b=$ the fraction of the dispersed oil not returning to the slick, $W=$ wind speed $(\mathrm{m} / \mathrm{s}), \mu=$ viscosity $(\mathrm{cp}), S_{t}=$ oil-water interfacial tension (dyne/m). $D_{d}$ and the $V_{m}$ are obtained from the catalogues of the dispersants and published data in National Emergency Management Agency [19].

\section{V1. Volume Change}

Volume change can be expressed as a function of the evaporation and removal process. In the case of volume change by an evaporation process, we assumed that the volume of the total mixture is the sum of the volume of the individual materials. Molecular interactions of individual ingredients in the mixture were ignored.

$$
\frac{d V}{d t}=\sum_{i=1}^{n} \frac{d m_{i}}{d t} \frac{1}{\rho_{i}}-D_{n} V-D_{d} V-V_{m}
$$

where $\rho_{i}=$ density of $\mathrm{i}^{\text {th }}$ component $\left(\mathrm{kg} / \mathrm{m}^{3}\right)$.

\section{Vll. Viscosity and Density}

An increase in viscosity due to mousse formation can be computed by the following equation [18]: 


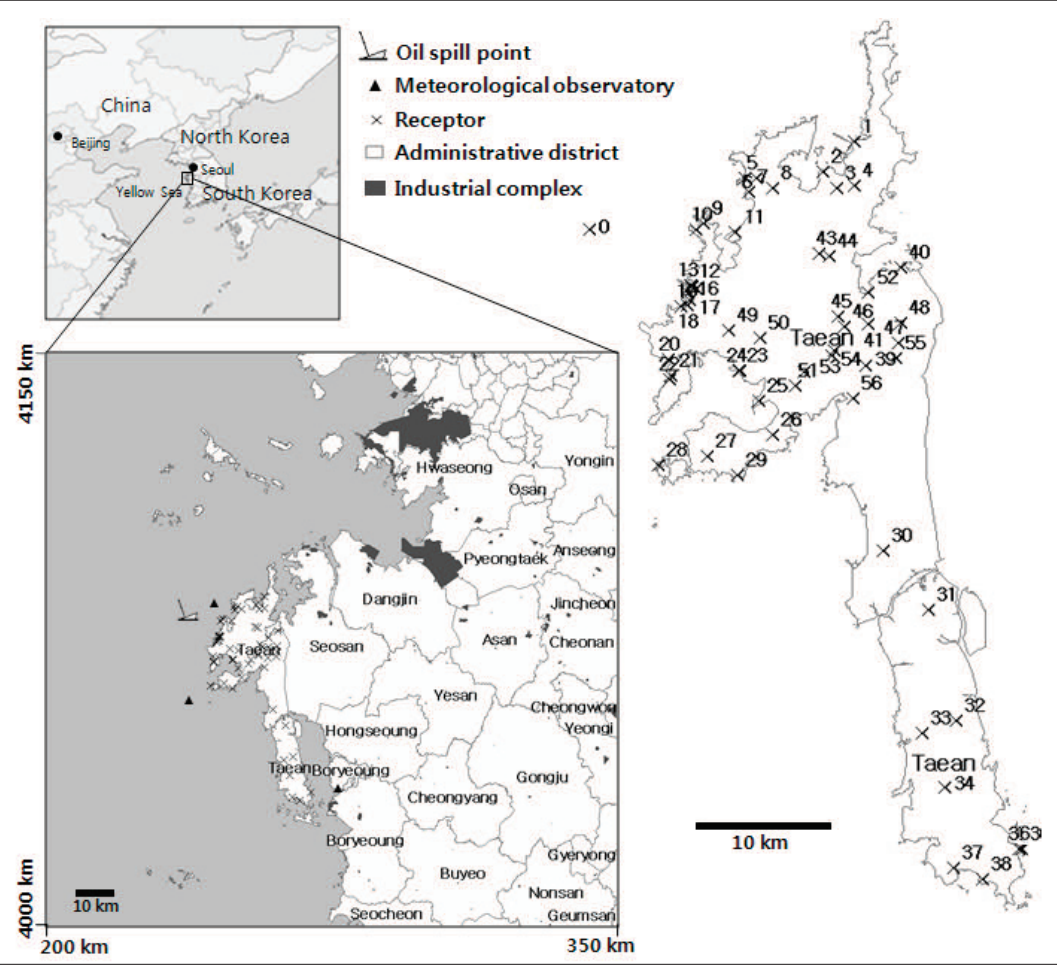

Figure 1. Geographical representation of the location of the oil spill and the area used in the simulation.

$$
\frac{d \mu}{d t}=C_{2} \mu \sum_{i=1}^{n} \frac{d m_{i}}{d t} \frac{1}{\rho_{i}}+\frac{2.5 \mu}{\left(1-C_{3} Y_{W}\right)} \frac{d Y_{W}}{d t}
$$

where $C_{2}=$ a constant between 1 and 10 , where 1 denotes for light substances such as gasoline, and 10 for crude oils, $C 3$ $=$ final fraction water content $(0.7$ for crude oils and heavy fuel oil). The density increase may be calculated by [9]:

$$
\rho=Y_{W} \rho_{W}+\left(1-Y_{W}\right)\left(\rho_{O}+C_{3} F_{E}\right)
$$

\section{Transport on the Sea Surface}

In order to calculate the horizontal dispersion of an oil slick on the sea surface, we analyzed satellite images and aerial photographs at specific times. The analyzed data were linked with the geographical information system (GIS). Finally the GIS-based snapshot of oil slick movement at a specific time was interpolated to estimate hourly motion.

\section{Airborne VOC Concentration}

The CALPUFF model was integrated with the weathering algorithm to simulate the air dispersion of oil components. CALPUFF is one of the most widely used unsteady-state air dispersion models. This model is suitable for calculating the space and time of various air dispersed states.

The location of the accident was approximately $8 \mathrm{~km}$ from the northwest of Malipo beach, the Taean district, Korea, $235.6 \mathrm{~km}$ on the $\mathrm{x}$ coordinate and $4,084.51 \mathrm{~km}$ on the $\mathrm{y}$ coordinate of the $52 \mathrm{~N}$ universal transverse mercator (UTM) coordinate system (Figure 1). This area around the Taean district, which extends from 200 to $350 \mathrm{~km}$ on the $\mathrm{x}$ coordinate and 4,000 to $4,150 \mathrm{~km}$ on the y coordinate of the 52 N UTM, was selected to run the model. To clearly discern the exposure level of volatile organic compounds in Taean, 57 numbered receptors were placed on the ocean floor, the coastline and the inland area.

The Korean Meteorological Administration [20] provides free, hourly meteorological data such as wind speed, wind direction, temperature, rainfall, snowfall, cloud cover, solar radiation, and air pressure. In this study, we used the three meteorological data sets from three sites (described as a triangle in Figure 1); An-do, Ong-do, and Boryeong. Terrain map and landuse maps of the area were obtained from the environmental geographic information system [21]. The meteorological and geographical data were preprocessed (using the California Meteorological preprocess model (CALMET) meteorological preprocess model in the CALPUFF model) according to a literature report [22] and a previous study [23]. The CALMET model permits additional information to be calculated, such as the height of the Planetary Boundary Layer using the Monin-Obukhov similarity theory. Finally the CAPUFF model was run by preprocessed data. 

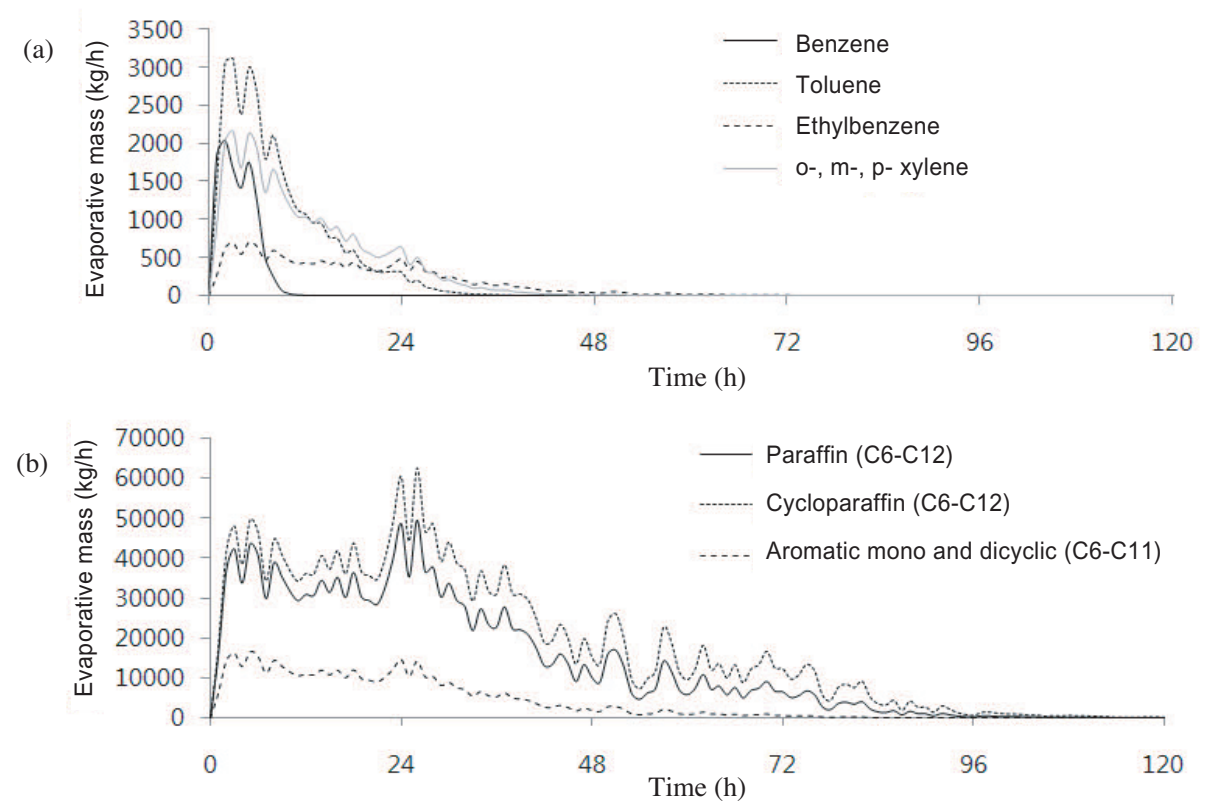

Figure 2. Evaporation rate of spilled oil with time; (a) representative toxic volatile organic compounds; (b) light components of crude oil.

\section{RESULTS}

Figure 2 represents the total rates of evaporation of benzene, toluene, ethylbenzene and xylene (BTEX), and paraffin (C6-C12), cycloparaffin (C6-C12) and aromatic mono and dicyclic components (C6-C11). These results were obtained through applying the measured meteorological and hydrological situation for the Hebei Spirit oil spill to the model. The rates of evaporation fluctuate with time because evaporation is strongly influenced by the temperature and wind velocity. As depicted in Figure 2, the evaporation of benzene is almost complete in 10 hours, toluene, ethylbenzene and xylene have all nearly completely evaporated within 48 hours and the other volatile organic compounds had evaporated within a period of 4 days. The maximum emission rates of BTEX, and paraffin (C6-C12), cycloparaffin (C6-C12) and aromatic mono and dicyclic components (C6-C11) are 2,042, 3,115, $697,2,171,49,580,62,549$ and $16,612 \mathrm{in} \mathrm{kg} / \mathrm{hr}$, respectively.

The tempo-spatial variation of atmospheric TVOCs [including BTEX and paraffin (C6-C12), cycloparaffin (C6C12) and aromatic mono and dicyclic components (C6C11)] concentrations is illustrated in Figure 3. Until 7:00, December 10 (48 hours after the oil spill accident), the TVOCs moved in a southeasterly direction, following the coastline from the accident point. After 7:00, December 9, the downwind direction gradually changed to the west from the southeast. Finally, on 7:00 December 10 (78 hours after the oil spill), the evaporated components did not move inland. The maximum air concentrations of TVOCs are about $100,000 \mathrm{\mu g} / \mathrm{m}^{3}$ on the ocean floor, $12,000 \mathrm{\mu g} / \mathrm{m}^{3}$ at the coastline and the area of human settlement.

Figures 4(a) - (c) illustrate the cumulative, maximum 1 hour averaged (1-hr) and maximum 8 hours averaged (8-hrs) concentrations for BTEX and TVOCs at each receptor point. The concentrations at 1-hour and 8-hours were selected from all of the recorded 1-hour and 8-hours averaged concentrations, therefore the data sampling times differed for chemical species and receptor sites. The receptor numbers can be broadly classified into 6 groups. Receptor number 0 represents the point of the oil spill on the ocean floor, receptors 1 to 4,5 to 11,12 to 22,23 to 29 and 30 to 38 are located to the north, northwest, west, southwest and south side of the Taean district, respectively (Figures 1 and 3). The other receptors are situated in inland areas.

On the ocean floor (receptor number 0), all cumulative VOCs concentrations are from 10 -fold to 1,000 -fold higher than the concentrations at the other sites. The cumulative concentrations of BTEX and TVOCs on this site were $24,364 \mathrm{\mu g} \cdot \mathrm{h} / \mathrm{m}^{3}, 42,716 \mathrm{\mu g} \cdot \mathrm{h} / \mathrm{m}^{3}, 11,722 \mathrm{\mu g} \cdot \mathrm{h} / \mathrm{m}^{3}, 33,978 \mu \mathrm{g} \cdot$ $\mathrm{h} / \mathrm{m}^{3}$ and $589,571 \mathrm{\mu g} \cdot \mathrm{h} / \mathrm{m}^{3}$. The lowest concentrations of BTEX and TVOCs were modeled at receptor numbers 1,2,3 and 4, the north side of Taean. It is noteworthy that the respective concentrations for BTEX and TVOCs at receptor number 1 are about 10,000-fold, 2,000-fold, 150-fold, 800-fold and 100-fold lower than the concentrations at the coastline and inland areas. The cumulative concentrations of BTEX and TVOCs at receptor number 1 are $0.003 \mathrm{~kg} \cdot \mathrm{h} / \mathrm{m}^{3}, 0.187 \mathrm{\mu g} \cdot \mathrm{h} / \mathrm{m}^{3}, 1.492 \mathrm{\mu g} \cdot$ $\mathrm{h} / \mathrm{m}^{3}, 0.511 \mathrm{\mu g} \cdot \mathrm{h} / \mathrm{m}^{3}$ and $545.193 \mathrm{\mu g} \cdot \mathrm{h} / \mathrm{m}^{3}$. The concentrations of toluene, ethylbenzene, xylene and TVOCs at the coastline and inland are similar; the range of concentrations are 115.6 574.4, 54 - 571.5, 117 - 783.6, and 9,585 - 162,463 $\mathrm{jg} \cdot \mathrm{h} / \mathrm{m}^{3}$, respectively. In the case of benzene, the concentrations at the 


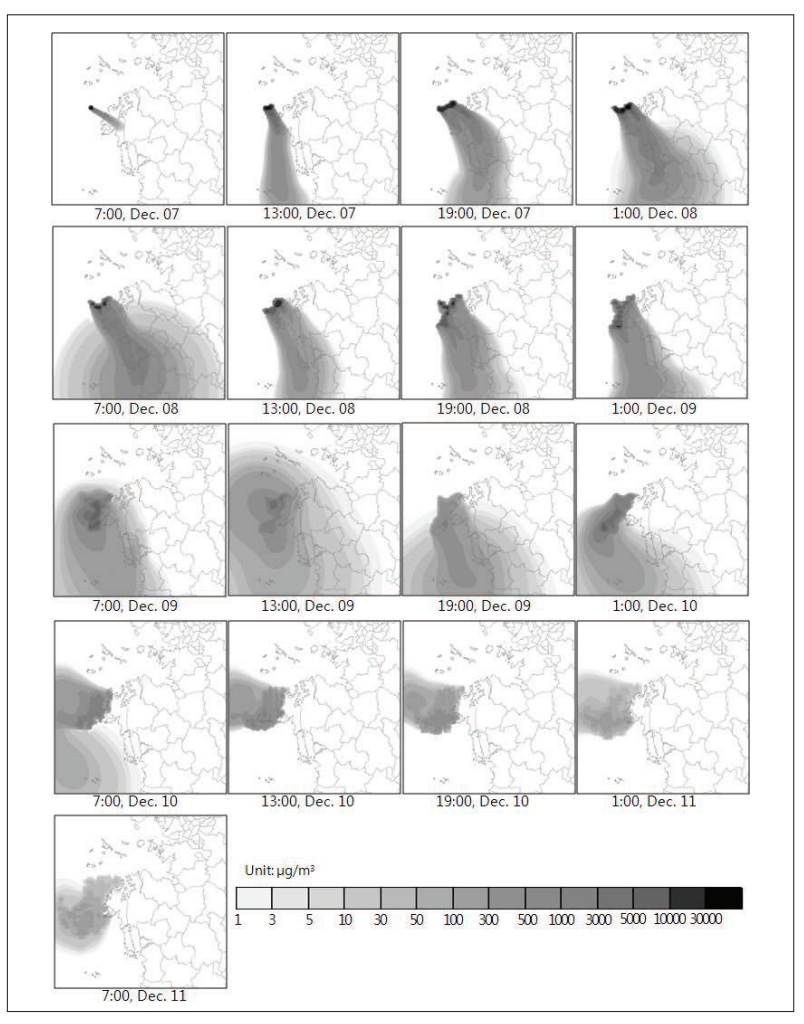

Figure 3. Contour plot of the concentration of total volatile organic compounds by time and space.

coastlines $\left(2.2\right.$ - $\left.106 \mu \mathrm{g} \cdot \mathrm{h} / \mathrm{m}^{3}\right)$ are, on average, 4 times higher than that at inland areas $\left(1-28.3 \mu \mathrm{g} \cdot \mathrm{h} / \mathrm{m}^{3}\right)$.

The spatial patterns for the concentration of toluene, ethylbenzene, xylene and TVOCs at 1 hour and 8 hours showed similar spatial patterns for cumulative concentrations. However, the cumulative concentrations for benzene are lower than ethylbenzene concentrations at each coast line, the 1-hour and 8-hours concentrations for benzene are similar to or higher than ethylbenzene concentrations at the coastline. This can be attributed to the high volatility of benzene and related meteorological conditions.

\section{DISCUSSION}

In early stage of an oil spill, several observations are usually carried out to confirm the airborne concentrations of BTEX. At 100 hours after the oil spill accident, the observed BTEX concentrations were 0.43-1.94 ppb, 0.58-1.59 ppb, $0.16-0.65 \mathrm{ppb}$ and $0.09-5.11 \mathrm{ppb}$, respectively [24]. The Ministry of Environment of Korea has been collecting data on these materials at monthly intervals. The annual average concentrations for these materials under normal conditions were $0.65 \mathrm{ppb}, 1.158 \mathrm{ppb}, 0.367 \mathrm{ppb}$ and $0.499 \mathrm{ppb}$ in the Taean area [21]. The difference in concentrations between normal conditions and the situation 100 hour after the oil spill were quite small. The reason for this is that the above four materials had completely evaporated in 48 hours, as shown in Figure 2(a), and because the wind direction changed to a westerly direction, the opposite direction from the Taean area by 78 hours after the oil spill (Figure 3). It necessarily follows that the observed concentration levels between normal conditions and 100 hours after the oil spill would be nearly the same. This result suggests that a national contingency plan for oil spill accidents must incorporate a monitoring plan that rapidly assesses the exposure of humans to VOCs.

Initial observation data for the airborne concentration of volatile organic components is not available for the first 100 hours, and the BTEX and TVOCs also evaporated very quickly. Therefore, it is not possible to directly confirm whether or not the modeled output from CALPUFF is accurate. This is the limitation of this study, which must contain precise values regarding concentration. So, we indirectly allowed some insight into the accuracy of the model with previously collected observation data taken from other oil spill cases. Jones et al. [25] performed a series of measurements on the concentration of airborne benzene over a water-filled moat at Little Sand Island in Mobile Bay in the US. In this study, almost all of the benzene had evaporated within about 8.5 hours. This result is consistent with our modeling results [Figure 2(a)] even if the environmental situations are different from the Hebei Spirit case. In addition, the benzene concentration above the oil slick was from a few thousand $\mu \mathrm{g} / \mathrm{m}^{3}$ to few ten thousand $\mu \mathrm{g} / \mathrm{m}^{3}$ for 8 hours. This is very similar to our results for the ocean floor [Figure 4(a)], in spite of the fact that the author's result tends to underestimate Jones's result. The underestimation is probably due to differences in meteorological and hydrological conditions, spill volume and receptor height (the receptor height of our modeling study was $1.5 \mathrm{~m}$ and the observation height of the previous study was $19 \mathrm{~mm}$ above the slick). It can thus be concluded that the accuracy of the modeled evaporation rate of volatile components is quite acceptable.

The emission rate for BTEX appears to be comparable with national data for emission rates [26,27]. The hourly emissions from an adjacent industrial complex (as depicted in Figure 1) for BTEX were, respectively, $7.7 \mathrm{~kg} / \mathrm{hr}, 47.2$ $\mathrm{kg} / \mathrm{hr}, 10.3 \mathrm{~kg} / \mathrm{hr}$ and $38.1 \mathrm{~kg} / \mathrm{hr}$ in 2007 . The values for the maximum evaporation of BTEX are 265, 66, 3,319 and 56 fold higher than the hourly industrial emissions of this area (Figure 2). This result clearly indicates that the airborne exposure level was abnormal, and supports the possibility that the clean-up workers and inhabitants living in adjacent areas were exposed to high levels of volatiles.

The data provide solutions to the question of when and where attention should be focused in investigations of the impact of such situations on human health such as this one (Figure 3). Many of the clean-up workers and most of the inhabitants in Taean probably inhaled the large amounts of 


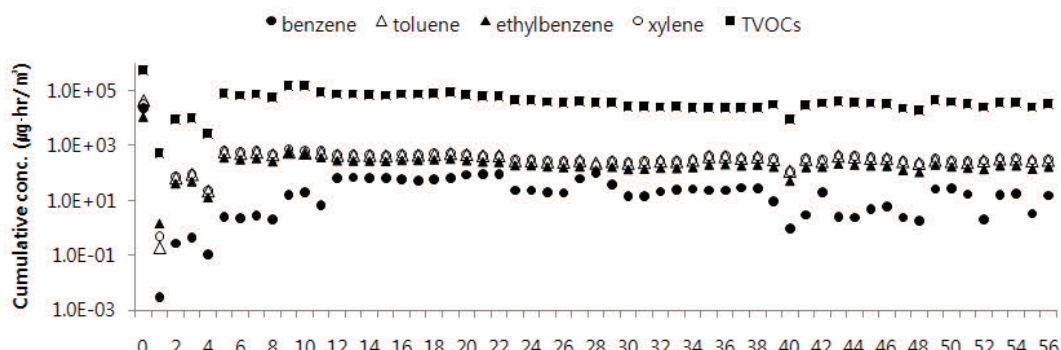

$\begin{array}{lllllllllllllllllllllllllllll}0 & 2 & 4 & 6 & 8 & 10 & 12 & 14 & 16 & 18 & 20 & 22 & 24 & 26 & 28 & 30 & 32 & 34 & 36 & 38 & 40 & 42 & 44 & 46 & 48 & 50 & 52 & 54 & 56\end{array}$

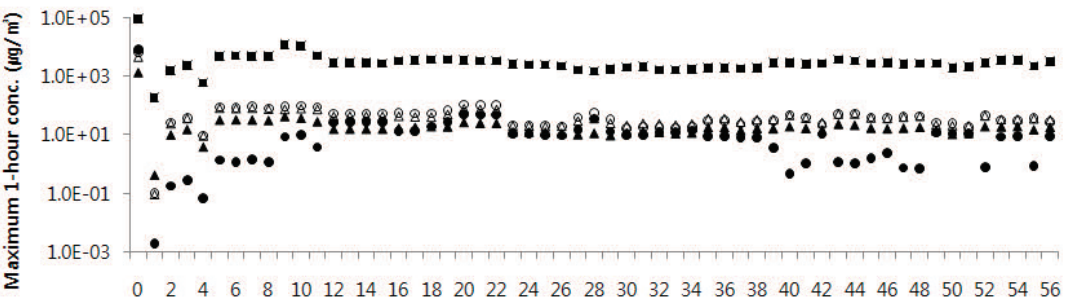

Site

(b)

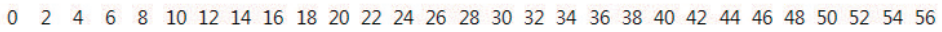

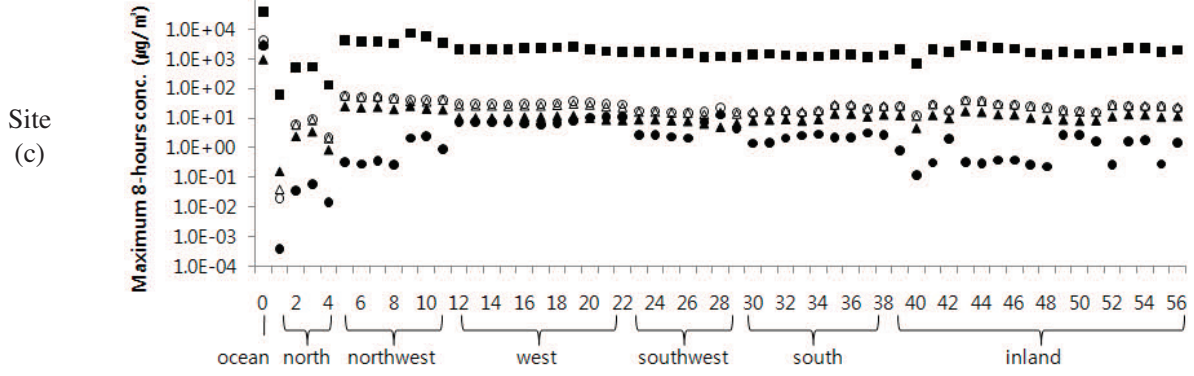

Figure 4. Concentrations of benzene, toluene, ethylbenzene, xylene and total volatile organic compounds by the receptor number.

a, cumulative concentrations; b, 1 hour averaged maximum concentrations; c, 8 hours averaged maximum concentrations.

VOCs at the initial stage of the spill, because the VOCs were transported in a southeasterly direction from location of the accident for a period of 3 days. After 7:00, December 10 (72 hours after the oil spill accident), the downwind direction changed to the west from the southeast direction. As a result, volatile components did not move toward the land. After this time, only clean-up workers on the ocean floor and at the coastal areas were exposed to excessive levels of VOCs. Clean-up workers on the ocean floor and on the coast line were exposed for more than 5 days, and inhabitants living in inland areas were exposed for 3 days. The population of the Taean area is about 64,000 , and a total of 59,155 clean-up workers including inhabitants $(9,887)$, police officers and army personnels $(15,273)$, firemans $(10,366)$, night guards $(1,700)$, Civil Defense Corps members $(2,663)$, the public officers $(7,093)$, and volunteers $(12,173)$ were involved in clean-up activities during the first 5 days. It would be expected that the exposure of humans to airborne volatile compounds might have an impact on the health of humans who live in the Taean coastal area, and especially clean-up workers who were exposed during the initial clean-up work (about 5 days). The inhabitants who live in the area north of Taean (receptor numbers 1,2,3 and 4 in Figure 1) were exposed to the lowest level of VOCs. These inhabitants could be used as a control group in investigating the health effects of volatile components.

The previous database on environmental criteria provides information on risk. The concentration from the occurrence of the oil spill was very high compared with the normal conditions. So, we compared the concentration with workplace standards for each material, containing a high level standard. The Ministry of Labor of Korea [28] has regulated the extent of labor exposure by the workplace standards contained by the Korean Occupational Safety and Health Act (KOSHA). The KOSHA standards include threshold limit value - time weighted average (TLV-TWA) and threshold limit value - short term exposure limit (TLVSTEL). TLV-TWA is based on an exposure period of 8 hours-per-day and a 40 hour-per-workweek schedule. TLVSTEL is the concentration that has been determined that workers can be continuously exposed for short periods of time. The TLV-TWA for benzene, toluene, ethylbenzene and xylene are $1 \mathrm{ppm}, 50 \mathrm{ppm}, 100 \mathrm{ppm}$ and $100 \mathrm{ppm}$ (approximately 3,000, 188,000, 435,000 and 435,000 in $\mathrm{\mu g} / \mathrm{m}^{3}$ ), and the TLV-STEL are $5 \mathrm{ppm}, 150 \mathrm{ppm}, 125 \mathrm{ppm}$ and $150 \mathrm{ppm}$ (approximately 16,000, 560,000, 545,000, and 
Table 2. Environmental air quality standards or guideline values with modeled maximum concentrations (various averaging time)

\begin{tabular}{|c|c|c|c|c|}
\hline Material & Standards or guidelines (averaging time) & Site & $\begin{array}{l}\text { Modeled maximum } \\
\text { concentrations } \\
\left(\mu \mathrm{g} / \mathrm{m}^{3}\right)\end{array}$ & Averaging time \\
\hline Benzene & $3-5 \mu \mathrm{g} / \mathrm{m}^{3}$ (annual average) $[31,37]$ & $\begin{array}{l}\text { Ocean } \\
\text { North } \\
\text { Coastline } \\
\text { Inland }\end{array}$ & $\begin{array}{c}2.78 \\
3.5 \mathrm{E}-7-5.3 \mathrm{E}-5 \\
2.5 \mathrm{E}-4-0.012 \\
1.1 \mathrm{E}-4-0.003\end{array}$ & $1 \mathrm{y}$ \\
\hline & $30 \mu \mathrm{gg} / \mathrm{m}^{3}(1 \mathrm{~h})[30]$ & $\begin{array}{l}\text { Ocean } \\
\text { North } \\
\text { Coastline } \\
\text { Inland }\end{array}$ & $\begin{array}{c}8,927.96 \\
0.002-0.28 \\
1.21-52.3 \\
0.48-13\end{array}$ & $1 \mathrm{~h}$ \\
\hline Toluene & $27-30 \mu \mathrm{gg} / \mathrm{m}^{3}(24 \mathrm{~h})[31]$ & $\begin{array}{l}\text { Ocean } \\
\text { North } \\
\text { Coastline } \\
\text { Inland }\end{array}$ & $\begin{array}{c}1,774.99 \\
9.76-23.56 \\
0.94-22.49 \\
0.007-24.26\end{array}$ & $24 \mathrm{~h}$ \\
\hline Ethylbenzene & $3800 \mu \mathrm{g} / \mathrm{m}^{3}(24 \mathrm{~h})[33]$ & $\begin{array}{l}\text { Ocean } \\
\text { North } \\
\text { Coastline } \\
\text { Inland }\end{array}$ & $\begin{array}{c}466.51 \\
5.56-18.92 \\
0.49-14.53 \\
0.006-15.65\end{array}$ & $24 \mathrm{~h}$ \\
\hline Xylene & $250 \mathrm{ppb}\left(1087.5 \mu \mathrm{gg} / \mathrm{m}^{3}\right)(24 \mathrm{~h})[32]$ & $\begin{array}{l}\text { Ocean } \\
\text { North } \\
\text { Coastline }\end{array}$ & $\begin{array}{c}2,799.35 \\
22.05-60.45 \\
1.97-53.95\end{array}$ & $24 \mathrm{~h}$ \\
\hline $\begin{array}{l}\text { Total volatile } \\
\text { organic } \\
\text { compounds }\end{array}$ & $300-500 \mu \mathrm{g} / \mathrm{m}^{3}(2$ h) [36] & $\begin{array}{l}\text { Inland } \\
\text { Ocean } \\
\text { North } \\
\text { Coastline } \\
\text { Inland }\end{array}$ & $\begin{array}{c}0.01-56.19 \\
95,175.65 \\
137.91-2,260.69 \\
1,387.92-10,552.1 \\
1,853.26-3,613.24\end{array}$ & $2 \mathrm{~h}$ \\
\hline
\end{tabular}

$655,000 \mathrm{in} \mathrm{g} / \mathrm{g} \mathrm{m}^{3}$ ). As shown in Figure 2, the 1-hour maximum concentrations for BTEX were lower than the TLV-TWA. The 8-hour maximum concentrations for toluene, ethylbenzene and xylene were also lower than the TLVSTEL at all spatial positions. However, in the case of benzene on the ocean floor, the 1-hr maximum concentration $\left(8,928 \mu \mathrm{g} / \mathrm{m}^{3}\right)$ is $56 \%$ the level of TLV-STEL, and the 8hours maximum concentration $\left(3,037 \mathrm{\mu g} / \mathrm{m}^{3}\right)$ is higher than that for TLV-TWA. The benzene concentration on the ocean floor failed to meet the workplace standards. These results corroborate the conclusion that the evaporated benzene could have had an adverse influence on the health of cleanup workers. Furthermore, the workplace standards were produced on the basis of normal healthy subjects; it has uncertainty in terms of assessing adverse effects on sensitive subgroups such as children, the elderly and pregnant women.

Other available toxicity data are the ambient air quality standards or guidelines for VOCs. We illustrate the air quality standards or guidelines and modeled concentrations in Table 2. The Korean government recently established a standard value for benzene in ambient air of an annualaverage of $5 \mathrm{\mu g} / \mathrm{m}^{3}$ which corresponds with the European Union recommended annual limit. These values are around $10^{-6}$ level in excess of carcinogenic risk based on the integrated risk information system [29]. The modeled annual average concentrations were $2.78 \mu \mathrm{g} / \mathrm{m}^{3}$ on the ocean and $0.01 \mathrm{\mu g} / \mathrm{m}^{3}$ (maximum value) at site number 28. The annual average concentrations met the environmental standards and the guide line values (although the modeled values were similar to the Japanese standard).

For the short-term criterion of air quality, Alberta Environment of Canada [30] published a guideline value for 1 -hr benzene concentrations $\left(30 \mathrm{\mu g} / \mathrm{m}^{3}\right)$. As shown in Figure 4(b), the maximum 1-hr benzene concentrations were 8,927 $\mathrm{\mu g} / \mathrm{m}^{3}$ on the ocean and 52.3, 49.95 and $49.95 \mathrm{\mu g} / \mathrm{m}^{3}$ at site numbers 20, 21 and 22, respectively. These values were much higher than the Alberta Environment guideline value. In the case of toluene, we compared our modeled data with the Swedish and WHO recommended air guidelines [31]. The modeled values at most of the receptor sites were lower than these guideline values; however the concentration on the ocean floor was 60 times higher than the guideline value. The Department of Environment and Heritage of the Austrian Government published guideline values for xylene [32]. The modeled xylene concentrations at coastal and inland areas were much lower than Austrian government guideline values. On the ocean floor, the modeled values were 2.57 fold higher than guideline values.

The other available criterion is the guideline values for indoor air quality. These guideline values were extensively arranged [33]. The guideline value for ethylbenzene is 3,800 $\mathrm{\mu g} / \mathrm{m}^{3}$, therefore the modeled ethylbenzene concentrations at all locations in Taean met the indoor air quality guideline value. The concentrations of TVOCs can be compared with the indoor air quality guideline values of TVOCs, although the ingredients and their portions are probably different from our 
TVOCs. As shown in Table 2, most of the modeled concentrations did not meet the guideline values at most of the sites in Taean, except for receptor number $1\left(137.91 \mu \mathrm{g} / \mathrm{m}^{3}\right)$. In a comparison study between the modeled results and air quality standards or guideline values, it can be concluded that the modeled concentration was clearly not within the acceptable guidelines of environmental quality. This suggests that the risk levels are probably quite high and it is possible that this had an adverse impact on human health. Therefore, follow-up studies were needed for the evaluation of the risk by BTEX and TVOCs.

The published short term epidemiological studies are consistent with this conclusion. Using our model outputs, several epidemiological studies were carried out, to evaluate the acute health effect on pregnant women and children, and the results have been published [24,34]. In these studies, pregnant women exposed to higher ambient cumulative levels of BTEX were significantly more likely to report skinrelated symptoms in the first day after the accident, and significantly more likely to report abdominal pain during the first through fourth days following the accident. Children who were exposed to high levels of BTEX reported more physical and mental symptoms than those who lived farther from the polluted coast line. These studies suggest that the exposure level to BTEX was abnormally high and is correlated with an increased risk of health effects among pregnant women and children. These results indirectly show that the modeled output has an acceptable accuracy for the tempo-spatial patterns of VOCs concentrations.

In this study, an integrated procedure for modeling oil slick weathering and atmospheric dispersion is proposed, in an attempt to understand the exposure level of volatile compounds in a crude oil spill. We conclude that our modeling study has the potential to enhance current exposure analysis techniques, that they are feasible, and can provide baseline information for future long term epidemiological studies. In the case of an oil spill near a heavily populated area (such as the Hebei Spirit oil spill), a modeling study of airborne exposure is significant.

From the labor environmental standards and air quality criteria, the findings showed that the exposure levels to clean-up workers and inhabitants were quite high. The results show that the adverse impact on humans is not only a possible short term effect but also may well persist for a longer term. Furthermore, future possible long-term impacts are unpredictable, because the available scientific data cannot predict the all possible adverse effects. Crude oil contains many types of hazardous compounds; therefore it is not possible to predict possible synergic effects between different compounds due to our current lack of knowledge. Therefore long term studies will be required to assess the adverse effect of events such as these on human health in the Taean area.

Despite the advantages of the modeling study, it is important to seek further improvements. Future studies will be required to verify the proposed modeling method, including a comparison study of model outputs with observation data on oil spill situations and an uncertainty analysis. Additional future work should be undertaken to simulate the long term exposure of concentrations of weak volatile compounds (e.g. polycyclic aromatic hydrocarbons, persistent organic pollutants) in the air.

\section{ACKNOWLEGEMENTS}

This study was supported by special Grant for the Investigation of Acute Health Effects of Hebei Spirit Oil Spill, Ministry of Environment, 2008.

\section{CONFLICT OF INTEREST}

The authors have no conflict of interest to declare on this study.

\section{REFERENCES}

1. Burgherr P. In-depth analysis of accidental oil spills from tankers in the context of global spill trends from all sources. J Hazard Mater 2007;140(1-2):245-256.

2. Morita A, Kusaka Y, Deguchi Y, Moriuchi A, Nakanaga Y, Iki $\mathrm{M}$, et al. Acute health problems among the people engaged in the cleanup of the Nakhodka oil spill. Environ Res 1999;81(3):185194.

3. Suárez B, Lope V. Pérez-Gómez B, Aragonés N, RodríguezArtalejo F, Marqués F, et al. Acute health problems among subjects involved in the cleanup operation following the Prestige oil spill in Asturias and Cantabria (Spain). Environ Res 2005; 99(3):413-424

4. Lyons RA, Temple JM, Evans D, Fone DL, Palmer SR. Acute health effects of the Sea Empress oil spill. J Epidemiol Community Health 1999;53(5):306-310.

5. Zock JP, Rodríguez-Trigo G, Pozo-Rodríguez F, Barberà JA, Bouso L, Torralba Y, et al. Prolonged respiratory symptoms in clean-up workers of the prestige oil spill. Am J Respir Crit Care Med 2007;176(6):610-616.

6. Drivas PJ. Calculation of evaporative emissions from multicomponent liquid spills. Environ Sci Technol 1982;16(10):726728.

7. Hoult DP. Oil spreading on the sea. Annu Rev Fluid Mech 1972; 4:341-368.

8. Yang WC, Wang H. Modeling of oil evaporation in aqueous environment. Water Res 1977;11(10):879-887.

9. Buchanan I, Hurford N. Methods for predicting the physical changes in oil spilt at sea. Oil Chem Pollut 1988;4(4):311-328.

10. Mackay D, Bruist IA, Mascarenhas R, Paterson S; University of Toronto, Dept. of Chemical Engineering; Canada, Environmental Emergency Branch, Research and Development Division, et al. Oil spill processes and models. Ottawa: Environment Canada; 
1980.

11. Lehr WJ, Fraga RJ, Belen MS, Cikerge HM. A new technique to estimate initial spill size using a modified fay-type spreading formula. Mar Pollut Bull 1984;15(9):326-329.

12. Stiver W, Mackay D. Evaporation rate of spills of hydrocarbons and petroleum mixtures. Environ Sci Technol 1984;18(11): 834-840.

13. Sebastião P, Soares CG . Modeling the fate of oil spills at sea. Spill Sci Technol Bull 1995;2(2-3):121-131.

14. Fingas MF. Modeling evaporation using models that are not boundary-layer regulated. J Hazard Mater 2004;107(1-2):27-36.

15. Chen H, Li D, Li X, Mathematical modeling of oil spill on the sea and application of the modeling in Daya Bay. J Hydrodyn 2007;19(3):282-291.

16. Xie H, Yapa PD, Nakata K. Modeling emulsification after an oil spill in the sea. J Mar Syst 2007;68(3-4):489-506.

17. Reed M. The physical fates component of the natural resource damage assessment model system. Oil Chem Pollut 1989;5(23):99-123.

18. Nazir M, Khan F, Amyotte P, Sadiq R. Multimedia fate of oil spills in a marine environment-an integrated modelling approach. Proc Saf Environ Protect 2008;86(2):141-148.

19. National Emergency Management Agency. Today's disaster situation display bulletin board. [cited 2012 Jan 31]. Available from: http://www.nema.go.kr/nema_c ms_iba/show_ nema/board/board1/list.jsp?c_relation=29\&check_the_num $=1$ 14\&check_the_code=4\&check_up_num=113 (Korean).

20. Korean Meteorological Administration. Terrestrial observation data. [cited 2012 Jan 31]. Available from: http://www. kma.go.kr/weather/observation/ currentweather.jsp (Korean).

21. Environmental Geographic Information System. Digital elevation model and land cover map. [cited 2012 Jan 31]. Available from: http://egis.me.go.kr/egis/home/ download/ DEM/index_dem.asp (Korean).

22. Seinfeld JH, Pandis SN. Atmospheric chemistry and physics: from air pollution to climate change. New York: Wiley; 1998, p. 766-915.

23. Kim JH, Kim MS, Kwak BK, Yoo HS, Shin CB, Yi J. Development of national scale environmental \& geographical information system for supporting exposure assessment. J Korean Soc Environ Eng 2006;28(10):1082-1089 (Korean).

24. Ministry of Environment. Investigation of acute health problems among people exposed to the Hebei Spirit oil spill. $1^{\text {st }}$ ed. Gwacheon: Ministry of Environment; 2008, p. 172-189 (Korean).

25. Jones RK; United States. National Oceanic and Atmospheric Administration; Hazardous Materials Response and Assessment Division. The evaporation of benzene and a series of alkanes from crude oil. Seattle, Wash: U.S. Dept. of Commerce, National Oceanic and Atmospheric Administration; 1992, p. 1-19.

26. Kim MS, Kim JH, Park HS, Sun YS, Kim HS, Choi K, et al. A new approach for estimating VOC emissions from anthropogenic non-point sources in urban communities. Korean J Chem Eng 2007;24(5):763-773.

27. Kim JH, Kwak BK, Park HS, Kim NG, Choi K, Yi J. A GISbased national emission inventory of major VOCs and risk assessment modeling: Part I - methodology and spatial pattern of emissions. Korean J Chem Eng 2009;27(1):129-138.

28. Ministry of Labor. Exposure limits for hazardous materials and physical agents. [cited 2012 Jan 31]. Available from: http://www.moel.go.kr/download.jsp?type=/bbs/\&file=\%C8\% AD\%C7\%D0\%B9\%B0\%C1\%FA\%20\%B9\%D7\%20\%B9\%B 0\%B8\%AE\%C0\%FB\%C0\%CE\%C0\%DA\%C0\%C7\%20\%B3 $\%$ ЕВ\%С3\%Е2\%B1\%Е2\%C1\%D8(\%B3\%ЕB\%B5\%BF\%BA $\% \mathrm{CE} \% \mathrm{~B} 0 \% \mathrm{ED} \% \mathrm{BD} \% \mathrm{C} 3 \% 20 \% \mathrm{C} 1 \% \mathrm{~A} 62010-44 \% \mathrm{C} 8 \% \mathrm{~A} 3)$. hwp (Korean).

29. U.S. Environmental Protection Agency. Benzene (CASRN 7143-2). [cited 2012 Jan 31]. Available from: http://www.epa.gov/ NCEA/iris/subst/0276.htm.

30. Government of Alberta Environment. Ambient air quality trends in alberta. [cited 2012 Jan 31]. Available from: http:// www.environment.alberta. ca/ documents/Ambient-AirQuality-Trends-in-Alberta-2008.pdf.

31. Kelessis AG, Petrakakis MJ, Zoumakis NM. Determination of benzene, toluene, ethylbenzene, and xylenes in urban air of Thessaloniki, Greece. Environ Toxicol 2006;21(4):440-443.

32. Department of Environment and Heritage of Austrian Government. Chemical reference guide. [cited 2012 Jan 31]. Available from: http://hermes.erin.gov.au/pls/crg_public/ !CRGPPUBLIC.PSTART?strAction=SearchByDocument\&int DocId $=5 \&$ rdoChemicalMode=NAME\&intChemicalId $=142 \&$ st rClassMedia $=$ n 2 Fa\&strClassSubclass1 $=$ n\%2Fa\&strClassSub class $2=\mathrm{n} \% 2 \mathrm{Fa} \&$ strClassSubclass $3=\mathrm{n} \% 2 \mathrm{Fa}$.

33. Anuma K, Uchiyama I, Ikeda K. The regulations for indoor air pollution in Japan: a public health perspective. J Risk Res 2008; 11(3):301-314.

34. Kim BM, Park E, LeeAn SY, Ha M, Kim EJ, Kwon H, et al. BTEX exposure and its health effects in pregnant women following the Hebei Spirit oil spill. J Prev Med Public Health 2009;42(2):96-103 (Korean).

35. Ministry of Land, Transport and Maritime Affairs. Weight fraction data gathering from opening of information. [cited 2012 Jan 31]. Available from: http://www.mltm.go.kr/ USR/WPGE0201/m_215/DTL.jsp (Korean).

36. Hippelein, M. Background concentrations of individual and total volatile organic compounds in residential indoor air of Schleswig-Holstein, Germany. J Environ Monit 2004;6(9): 745-752.

37. Ministry of the Environment Government of Japan. Environmental quality standards in Japan-air quality. [cited 2012 Jan 31]. Available from: http://www.env.go.jp/en/air/ aq/aq.html. 